\title{
Isolation and Biochemical Analysis of Bacteria associated with Dried Stigma of Saffron (Crocus sativus)
}

\author{
Mridhu Sharma*, Puneet Gupta, Shanu Mangotra, Sneha Ganjoo, \\ Deepika Trakroo, Sakshi Sharma and Jyoti Vakhlu
}

\author{
Department of Biotechnology, University of Jammu, School of Biotechnology, Baba Saheb \\ Ambedkar Road, Jammu, Tawi (J\&K) -180006, India \\ *Corresponding author
}

\section{Keywords}

Microbiome, plants, temperature,

moisture and $\mathrm{pH}$

Article Info

Accepted:

12 April 2021

Available Online:

10 May 2021

\section{A B S T R A C T}

The stigma and pistil of saffron are used to extract chemical compounds such as crocin, picrocrocin, crocetin and safranal; and volatile oils for flavor respectively. The work is to isolate microbiome associated with stigma of saffron. 15 morphotypes obtained from Kashmir and 32 from Kishtwar. Their morphological characterization showed that the smooth textured colonies more in Kishtwar and rough textured colonies more in Kashmir. The $\mathrm{IC}_{50}$ values of radical scavenging revealed that antioxidant activity of Kishtwar is more as lower $\mathrm{IC}_{50}$ value corresponds to a higher antioxidant activity of sample. The $\mathrm{IC}_{50}$ values of ferrous chelation revealed that antioxidant activity of Kishtwar is more as lower $\mathrm{IC}_{50}$ value corresponds to a higher antioxidant activity of sample. Hence, Kishtwar has more antioxidant activity. The flavonoid and phenolic content of Kashmir is higher than that of Kishtwar. Of the biochemical assays conducted, only tannins and Glycosides are present in stigma of saffron. Further work can be done to unveil the bacterial property to produce the pigments that act as favouring agent that can be used in bioindustry.

\section{Introduction}

Various studies on the plants have revealed that plants genome contributes to the structure and function of the plant microbiome and also the interations between host (plant) and the microorganisms. According to these studies the microbiome can be considered as an extension of the host genome. Microbiomes associated with above-ground (phyllosphere), below-ground (rhizosphere) (Oldroyd et al., 2011; Kent et al., 2002) and internal (endosphere) tissues of the same plant and those occupying the same niche of different plants have been studied (Gilbert et al., 2010; Tumbaugh et al., 2007) and it was seen to be 
very different, particularly when the microbiome is viewed at fine taxonomic levels such as genus, species and strain.

Specific metabolic capabilities are required to use host-derived carbon sources and tolerate host defenses; abiotic conditions, such as temperature, moisture and $\mathrm{pH}$. Thus, it becomes necessary to study microbial association to unravel the role of microbes in plant growth promotion. Piriformospora indica, an endophytic fungus colonizes the roots of a variety of plant species and promotes their growth The stigmas are covered by glandular trichoms cuticle wrinkles and scale wax (Negbi et al., 1999).

It contains many chemical compounds that are antioxidants such as alpha-crocin, zea-xanthin, lycopene, carotenes etc (Wani et al., 2012). Flower pistil contains volatile oils which gives pleasant flavor such as safranal, phenethenol, cincole, pinene, borneol, geraniol, limonene, para-cymene, linaloan, terpinen-4-ol etc. KimKwon and co-workers, 2012 reported that bacteria 5B6 (Bacillus sp.) has the potential to colonize in the phyllosphere and act as a biocontrol agent. The number of shoot sprouts significantly decreased beyond the untreated controls. The quantity of crocin, picrocrocin, crocetin and safranal compounds extracted from stigma of saffron was high in the plants which were soil drenched with Bacillus spore solution 14 weeks after sowing date.

Plant growth-promoting rhizobacteria, Pseudomonas and Bacillus species, have been applied to many agricultural crops to enhance, plant biomass, and/or disease control (Chen et al., 2007). The treatment conditions that yielded the best growth produced only modest improvements in a few saffron constituents.

Study of bacterial diversity associated with stigma of saffron from Kashmir and Kishtwar using Metagenomic approach. Isolation of bacterial diversity associated with stigma of saffron from Kashmir and Kishtwar using cultivation based approach. To compare the antioxidant properties, phenolic content, flavonoid contents and chemical analysis of bacteria isolated from stigma of saffron from Kashmir and Kishtwar.

\section{Materials and Methods}

The microbial diversity was analyzed from the stigma samples collected from Kishtwar and Kashmir using the culture dependent and culture independent approaches. The saffron is well known to be grown in Jammu and Kashmir (longitude: $34^{\circ} 5^{\prime} 24^{\prime \prime} \mathrm{N}$; latitude: $74^{\circ} 47^{\prime} 24^{\prime \prime}$ and altitude $1585 \mathrm{mts}$. above sea level). The stigma of Kashmir and Kishtwar were dried in J\&K Agricultural department, Jammu. The dried stigma of Kashmir and Kishtwar were collected from J\&K Agricultural department, Jammu.

\section{Microbial diversity analysis using cultivation independent approach}

Three methods were used i.e. Pang's method (2011); Wetcher's method (2013); and Zhao's method (2011). The three procedures are as follows:

\section{Pang's et al., 2011}

Modified chemical lysis method was carried out for Metagenomic DNA extraction by Yeates et al., (1998). $20 \mathrm{~g}$ stigma was suspended in $50 \mathrm{ml}$ DNA extraction buffer [100 mMTris- $\mathrm{HCl}$ (pH 8.0), $100 \mathrm{mM}$ sodium EDTA (pH 8.0), $1.5 \mathrm{M} \mathrm{NaCl}]$ and $1 \mathrm{ml}$ of Lysozyme $(10 \mathrm{mg} / \mathrm{ml})$ was added and the sample was incubated at $37^{\circ} \mathrm{C}$ for $1 \mathrm{~h}$. Then in sample, $2 \mathrm{ml} \mathrm{SDS}(20 \%, \mathrm{w} / \mathrm{v})$ and $15 \mu \mathrm{l}$ of proteinase $\mathrm{K}(20 \mathrm{mg} / \mathrm{ml})$ were added and it was further incubated at $65^{\circ} \mathrm{C}$ with $2 \mathrm{~h}$. The mixture was then centrifuged at $6,000 \mathrm{rpm}$ for $10 \mathrm{~min}$ to remove stigma residues. Supernatant was then transferred into a clean 
tube, and then precipitated by using halfvolume of PEG (30\%, w/v) / $\mathrm{NaCl}(1.6 \mathrm{M})$ and incubated at room temperature for another $2 \mathrm{~h}$. Then DNA was pelleted and resuspended in $20 \mathrm{ml}$ of TE (10 mMTris-HCl, $1 \mathrm{mM}$ sodium EDTA, $\mathrm{pH}$ 8.0). Further purification of this metagenomic DNA extract was done by using equal volume of P:C:I (phenol/ chloroform/ isoamyl-alcohol (25:24:1)). Subsequently the metagenomic DNA was precipitated with 0.1 volume of $\mathrm{NaCl}(5 \mathrm{M})$ and 2.5 volume of absolute ethanol. The DNA pellet was then recovered by centrifugation at $13,000 \mathrm{rpm}$ for $30 \mathrm{~min}$. DNA pellet was washed by $70 \%(\mathrm{v} / \mathrm{v})$ ethanol, air-dried and dissolved in $1 \mathrm{ml} \mathrm{TE}$.

\section{Zhao's method; 2011}

For sodium dodecyl sulfate (SDS)-based DNA extraction CTAB was used in the buffer. Stigma samples of $5 \mathrm{~g}$ were mixed with 13.5 $\mathrm{ml}$ of DNA extraction buffer (100 mMTris$\mathrm{HCl}$ [pH 8.0], $100 \mathrm{mM}$ sodium EDTA [pH 8.0], $100 \mathrm{mM}$ sodium phosphate [pH 8.0], 1.5 $\mathrm{M} \mathrm{NaCl}, 1 \% \mathrm{CTAB}$ ) and in centrifuge tubes $100 \mathrm{ml}$ of proteinase $\mathrm{K}(10 \mathrm{mg} / \mathrm{ml})$ was added by shaking at $225 \mathrm{rpm}$ for $30 \mathrm{~min}$ at $37^{\circ} \mathrm{C}$. After the shaking treatment, $1.5 \mathrm{ml}$ of $20 \%$ SDS was added, with gentle end-over-end inversions every 15 to $20 \mathrm{~min}$., the samples were incubated in a $65^{\circ} \mathrm{C}$ water bath for $2 \mathrm{~h}$. The supernatants were collected after centrifugation at 6,000 $3 \mathrm{~g}$ for $10 \mathrm{~min}$ at room temperature and transferred into $50 \mathrm{ml}$ centrifuge tubes. By adding $4.5 \mathrm{ml}$ of the extraction buffer and $0.5 \mathrm{ml}$ of $20 \%$ SDS, vortexing for $10 \mathrm{~s}$ and incubating at $65^{\circ} \mathrm{C}$ for $10 \mathrm{~min}$, centrifuged as before, the DNA was extracted two more times. Supernatants from the three cycles of extractions were combined and mixed with an equal volume of chloroform/isoamyl alcohol (24:1, v/v). The aqueous phase was recovered by centrifugation and precipitated with 0.6 volume of iso-propanol at room temperature for $1 \mathrm{~h}$. The pellet of crude nucleic acids was obtained by centrifugation at 16,000gfor 20 min at room temperature, washed with cold $70 \%$ ethanol, and resuspended in sterile deionized water, to give a final volume of 500 $\mathrm{ml}$.

\section{Wetcher's et al., 2013}

In $2 \mathrm{ml}$ microcentrifuge tube containing one milliliter of sterile PPB ( $\mathrm{pH} \mathrm{7.2)} \mathrm{was} \mathrm{added} \mathrm{to}$ $500 \mathrm{mg}$ of stigma. After vortexing for $1 \mathrm{~min}$ at high speed, the mixture was centrifuged at $325 \mathrm{~g}$ for $30 \mathrm{~s}$ in a microcentrifuge. The supernatant was then transferred to a $1.5 \mathrm{ml}$ microcentrifuge tube and $400 \mathrm{ml}$ of polyvinylpolypyrrolidone slurry $(100 \mathrm{mg} / \mathrm{ml}$ PVPP in $\mathrm{PPB}$ at $\mathrm{pH}$ 7.2) was added using a large-bore pipette tip, and the mixture was vortexed at high speed for $30 \mathrm{~s}$. To this, $2 \mathrm{ml}$ of $3 \mathrm{M} \mathrm{CaCl}_{2}$ was added, and the microcentrifuge tube was vortexed for $30 \mathrm{~s}$ and centrifuged as stated above. The supernatant was then transferred carefully to a clean $1.5-\mathrm{ml}$ microcentrifuge tube, to which $20 \mathrm{ml}$ of a lysozyme solution $(25 \mathrm{mg} / \mathrm{ml})$ and $10 \mathrm{ml}$ of a proteinase $\mathrm{K}$ solution $(20 \mathrm{mg} / \mathrm{ml})$ were added. The tube was inverted several times to mix the contents and placed in a $37^{\circ} \mathrm{C}$ water bath for $10 \mathrm{~min}$ and then placed in a $55^{\circ} \mathrm{C}$ water bath for $10 \mathrm{~min}$. Thirty micro liters of $20 \%$ (w/v) SDS was added to the tube and the contents were mixed by inverting several times, and the tube was placed in an $80^{\circ} \mathrm{C}$ water bath for $10 \mathrm{~min}$. Immediately after removal from the water bath, $400 \mathrm{ml}$ of the PVPP slurry was added to the contents of the tube which was mixed by gentle inversion, placed on ice for $5 \mathrm{~min}$, and then centrifuged at $16,000 \mathrm{~g}$ for $10 \mathrm{~min}$. The supernatant was transferred to a clean $1.5 \mathrm{ml}$ microcentrifuge tube followed by the addition of 0.7 volumes of $100 \%$ iso-propanol, the tube was inverted several times and centrifuged at $16,000 \mathrm{~g}$ for $5 \mathrm{~min}$. After centrifugation, the supernatant was discarded and the remaining pellet was washed in $500 \mathrm{ml}$ of $70 \%$ ethanol, 
centrifuged for $5 \mathrm{~min}$ at $16,000 \mathrm{~g}$, and air dried for $5 \mathrm{~min}$. The resulting pellet was resuspended in $25 \mathrm{ml}$ of TE.

\section{Microbial diversity analysis using cultivation dependent approach}

Eight different media i.e. Nutrient Agar (NA), (LB), (R-2-A), Water agar (WA), Czapek Dox Agar (CD), Soyabean Casein Digest Agar (SCD), King's B medium Base Agar, Minimal Agar(MA) were used. The $0.4 \mathrm{gm}$ of stigma was mixed in $18 \mathrm{ml}$ of Milli-Q. This solution was incubated at $37^{\circ} \mathrm{C}$ for 1 day. The quantity of Milli-Q was kept more than the required quantity as the stigma soaked 3-4 $\mathrm{ml}$ of MilliQ. There is no osmotic shock to the bacteria because the saffron provides the conditions to inhibit the osmotic shock.

These dilutions were spread on the plates of nine media prepared and autoclaved previously and incubated at $37^{\circ} \mathrm{C}$ for bacterial isolates. The saffron stigma was crushed in previously autoclaved pestle mortar so that both the endophytes and exophytes can be isolated separately.

To check the gram positive and gram negative bacteria

The pure colonies were isolated and the Gram's staining was done to check for gram positive and gram negative bacteria. The shape of bacteria was also analyzed.

Antioxidant, Flavonoid, Phenolic and Biochemical assay of the bacterial isolates

\section{Antioxidant activity}

Isolated bacterial cultures from Kashmir and Kishtwar were aggregated separately and their extract was prepared. This extract was taken at different concentrations $(20 \mu 1,40 \mu 1,60 \mu 1$, $80 \mu 1$ and $100 \mu 1)$ of Kashmir and Kishtwar.

\section{DPPH radical scavenging assay}

To the extract methanol was added and the volume was raised to $1000 \mu 1$. To this $1 \mathrm{ml}$ DPPH (prepared in methanol) add $2 \mathrm{ml}$ acetate buffer were added and the mixture was incubate for $30 \mathrm{~min}$. in dark. The OD was taken at $517 \mathrm{~nm}$. Measurement of radical inhibition properties of C. sativus was carried out according to the method described by Braca et al., (1971) with some modifications. Ascorbic acid was used as positive control and $\%$ inhibition was determined according to the following equation

\section{\%Inhibition \\ $=\frac{\text { Control OD }- \text { Sample OD }}{\text { Control OD }} \times 100$}

Three experimental replicates were taken for the assay. The $\mathrm{IC}_{50}$ values were calculated as the concentration of extracts causing 50\% inhibition of DPPH radical, a lower $\mathrm{IC}_{50}$ value corresponds to a higher antioxidant activity of sample.

\section{Ferrous chelation}

To the extract methanol was added and the volume was raised to $3 \mathrm{ml}$. To this $60 \mu \mathrm{l}$ of $\mathrm{FeCl}_{2}$ and $120 \mu \mathrm{l}$ of Ferrozine were added and OD was taken at $562 \mathrm{~nm}$. Measurement of radical scavenging properties of $\mathrm{C}$. sativus was carried out according to the method described by Carter et al., (1971) with some modifications. Gallic acid was used as positive control and \% scavenging was determined according to the following equation:

\section{\%Scavenging \\ $=\frac{\text { Control OD }- \text { Sample OD }}{\text { Control OD }} \times 100$}

Three experimental replicates were taken for the assay. The $\mathrm{IC}_{50}$ values were calculated as the concentration of extracts causing 50\% 
scavenging of ferrous ions, a higher $\mathrm{IC}_{50}$ value corresponds to a higher antioxidant activity of sample.

\section{Phenolic content}

To the extract distilled water was added to raise the volume to $1 \mathrm{ml}$. To this $1 \mathrm{ml} \mathrm{FC}$ reagent and $300 \mu 1$ of $\mathrm{NA}_{2} \mathrm{CO}_{3}$ was added and OD was taken at $765 \mathrm{~nm}$.

\section{Flavonoid content}

To the extract distilled water was added to raise the volume to $3 \mathrm{ml}$. To this $300 \mu \mathrm{l}$ $\mathrm{NaNO}_{2}$ was added and incubated for $5 \mathrm{~min}$. To this $300 \mu \mathrm{l} \mathrm{AlCl}_{3}$ was added and incubated at 6 min. Then $2 \mathrm{ml} \mathrm{NaOH}$ was added to $2.4 \mathrm{ml}$ distilled water and OD was taken at $510 \mathrm{~nm}$.

\section{Biochemical assay}

\section{Test for Tannins}

To $20 \mu 1$ sample $980 \mu 1$ methyl-hydroxide was added. To this $1 \mathrm{ml}$ of $5 \%$ ferrous chloride $\left(\mathrm{FeCl}_{3}\right)$ was added. Formation of bluish or greenish black precipitates shows that the presence of Tannins.

\section{Test for Saponins}

To $20 \mu 1$ sample $980 \mu 1$ methyl-hydroxide was added. To this $2.5 \mathrm{ml}$ of distilled water was added and shook vigorously. Then some drops of refined oil were added. Formation of foam shows presence of Saponins.

\section{Test for Coumerins}

To $20 \mu 1$ sample $980 \mu 1$ methyl-hydroxide was added. To this $1 \mathrm{ml}$ of $10 \%$ sodium-hydroxide $(\mathrm{NaOH})$ and $1 \mathrm{ml}$ chloroform was added. Yellow colour of solution shows the presence of Coumerins.

\section{Test for Terpenoids}

To $20 \mu 1$ sample $980 \mu 1$ methyl-hydroxide was added. To this $1 \mathrm{ml}$ chloroform and $1.5 \mathrm{ml}$ of concentrated sulphuric acid $\left(\mathrm{H}_{2} \mathrm{SO}_{4}\right)$ was added. The reddish brown colouration at the interface shows the presence of Terpenoids.

\section{Test for Quinones}

To $20 \mu 1$ sample $980 \mu 1$ methyl-hydroxide was added. To this $1 \mathrm{ml}$ of diluted $\mathrm{NaOH}$ was added. Blue- green or red colour shows the presence of Quinone.

\section{Test for Glycosides (Keller-Killani test)}

To $20 \mu 1$ sample $980 \mu 1$ methyl-hydroxide was added. To this $2 \mathrm{ml}$ GAA and one drop of $\mathrm{FeCl}_{3}$ and $1 \mathrm{ml}$ of concentrated $\mathrm{H}_{2} \mathrm{SO}_{4}$ was added.

Brown ring at the interface indicates the presence of de-oxy sugar characteristics of Glycosides. A violet ring may appear below brown ring. White or greenish ring may form uniformly throughout the acetic acid layer.

\section{Results and Discussions}

\section{Microbial diversity analysis using cultivation independent approach}

The DNA obtained was by all the three methods i.e. Pang's; Zhao's and Wetcher's method but the DNA obtained was not in the purified form and need standardization of new protocol especially for stigmal isolations. $0.8 \%$ agarose gel was prepared for analysis of isolated DNA samples: a) Control DNA shown in well no 4 and 5 ; b) Well numbers 1 and 6 show metagenomic DNA isolated by Pang's method from stigma of Kashmir and Kishtwar respectively; c) Well numbers 2 and 7 show metagenomic DNA isolated by Zhou's method from stigma of Kashmir and Kishtwar 
respectively; d) Well numbers 3 and 8 show metagenomic DNA isolated by Wetcher's method from stigma of Kashmir and Kishtwar respectively.

Microbial diversity analysis using cultivation dependent approach

The various morphotypes were isolated shown in Table I.

\section{Antioxidant activity}

\section{DPPH scavenging property}

The graph shows that microbial extract of Kishtwar has more DPPH scavenging activity than that of microbial extracts of Kashmir. Hence, Kishtwar has more antioxidant activity.

\section{Ferrous chelation antioxidant property}

The graph shows that ferrous chelation property is more in case of microbial extracts from Kashmir than that of the microbial extracts from Kishtwar. Hence, Kishtwar has more antioxidant activity.

\section{Antioxidant DPPH percentage scavenging and Ferrous percentage chelation properties of the extracts of the bacterial isolates}

The metagenomic DNA has been extracted from soil, rhizosphere, corms and other underground parts of the plant but no Metagenomic DNA isolation has been done from the upper parts of the flower like stigma, leaves, etc. The protocol used for the isolation of DNA from stigma does not produce purified DNA and had protein and other contaminants and so could not be sequenced and needs optimization. The bacteria isolated from the stigma were all grams positive rods or cocci and no grams negative bacteria were isolated. The morphotypes obtained from Kashmir are 15 and from Kishtwar are 23. The smooth textured colonies were more in Kishtwar than Kashmir and rough textured colonies were more in Kashmir than in Kishtwar. Yellow coloured colonies are more in Kishtwar whereas white coloured colonies are more in Kashmir. Pale-coloured colonies are same in both the cases. Kashmir has one orange coloured colony.

Table.1 Morphotypes obtained using different media

\begin{tabular}{|l|c|c|}
\hline Name of media & Kishtwar & Kashmir \\
\hline R-2-A Agar media & 5 & 7 \\
\hline Water Agar media & 1 & - \\
\hline Soyabean Casein Digest media & 4 & 1 \\
\hline NA Agar media & 6 & 4 \\
\hline LB Agar media & 6 & 3 \\
\hline Czapek Dox media & 1 & - \\
\hline King's B Agar media & - & - \\
\hline Minimal Agar media & - & 3 \\
\hline
\end{tabular}

The morphotypes obtained a) from Kashmir are 15 and b) from Kishtwar are 23. 
Table.2 Bacterial isolates from Kishtwar

\begin{tabular}{|c|c|c|c|c|c|c|}
\hline $\begin{array}{l}\text { Name of } \\
\text { organism }\end{array}$ & Plate & Shape & Texture & Colour & $\begin{array}{c}\text { Gram's } \\
\text { Stain }\end{array}$ & Shape \\
\hline SN1 & LB & Flower like & Rough & White & Positive & Cocci \\
\hline SN2 & LB & Mat forming & Smooth & Pale yellow & Positive & Rod \\
\hline SN3 & LB & Round & Smooth & Yellow & Positive & Rod \\
\hline SN4 & LB & Round & Smooth & Yellow & Positive & Cocci \\
\hline SN5 & NA & $\begin{array}{l}\text { Concentric } \\
\text { ring like }\end{array}$ & Smooth & Yellow & Positive & Cocci \\
\hline SN6 & R-2-A & $\begin{array}{l}\text { Concentric } \\
\text { ring like }\end{array}$ & Smooth & White & Positive & Cocci \\
\hline SN7 & SCD & Round & $\begin{array}{l}\text { Shiny, } \\
\text { smooth }\end{array}$ & Yellow & Positive & Cocci \\
\hline SN8 & R-2-A & Round & Smooth & White & Positive & Cocci \\
\hline SN9 & SCD & Mat forming & Smooth & Yellow & Positive & Cocci \\
\hline SN10 & $\mathrm{CD}$ & Irregular & Slimy & Yellow & Positive & Cocci \\
\hline SN11 & SCD & Irregular & Slimy & Yellow & Positive & Cocci \\
\hline SN12 & NA & Round & Smooth & Yellow & Positive & Cocci \\
\hline SN13 & NA & Round & Smooth & Yellow & Positive & Cocci \\
\hline SN 14 & LB & Flower like & Smooth & White & Positive & Cocci \\
\hline SN 15 & WA & Round & Smooth & Pale yellow & Positive & Cocci \\
\hline SN 16 & LB & Round & Smooth & Yellow & Positive & Cocci \\
\hline SN 17 & R-2-A & $\begin{array}{l}\text { Concentric } \\
\text { ring like }\end{array}$ & Smooth & Yellow & Positive & Cocci \\
\hline SN 18 & R-2-A & Flower shaped & Smooth & White & Positive & Cocci \\
\hline SN 19 & R-2-A & Round & Smooth & White & Positive & Cocci \\
\hline SN 20 & NA & Round & Smooth & Yellow & Positive & Cocci \\
\hline SN 21 & NA & Round & Smooth & Yellow & Positive & Cocci \\
\hline SN 22 & SCD & Mat forming & Smooth & Yellow & Positive & Rod \\
\hline SN 23 & NA & Round & Smooth & Yellow & Positive & Cocci \\
\hline
\end{tabular}


Table.3 Bacterial isolates from Kishtwar

\begin{tabular}{|c|c|c|c|c|c|c|}
\hline $\begin{array}{c}\text { Name of } \\
\text { organism }\end{array}$ & Plate & Shape & Texture & Colour & $\begin{array}{c}\text { Gram's } \\
\text { Stain }\end{array}$ & Shape \\
\hline SN a & NA & Round & Smooth & Yellow & Positive & Cocci \\
\hline SN b & NA & Mat forming & Smooth & White & Positive & Cocci \\
\hline SN c & NA & $\begin{array}{l}\text { Mat with } \\
\text { thread like } \\
\text { structures }\end{array}$ & $\begin{array}{l}\text { Feathery to } \\
\text { touch }\end{array}$ & Yellow & Positive & Cocci \\
\hline SN d & R-2-A & Mat forming & Smooth & White & Positive & Cocci \\
\hline SN e & R-2-A & Round & Smooth & White & Positive & Cocci \\
\hline SN f & R-2-A & Round & Smooth & $\begin{array}{l}\text { Pale } \\
\text { Yellow }\end{array}$ & Positive & Cocci \\
\hline SN g & SCD & Round & Smooth & $\begin{array}{l}\text { Pale } \\
\text { Yellow }\end{array}$ & Positive & Cocci \\
\hline SN h & R-2-A & $\begin{array}{l}\text { Mat with } \\
\text { thread like } \\
\text { structures }\end{array}$ & Feathery & White & Positive & Cocci \\
\hline SN i & R-2-A & Mat forming & Smooth & White & Positive & Cocci \\
\hline $\mathbf{S N} \mathbf{j}$ & R-2-A & $\begin{array}{l}\text { Concentric } \\
\text { ring like }\end{array}$ & Smooth & White & Positive & Cocci \\
\hline SN k & R-2-A & Round & Smooth & White & Positive & Cocci \\
\hline SN I & MM & Round & Smooth & White & Positive & Cocci \\
\hline SN m & MM & Round & Smooth & Orange & Positive & Cocci \\
\hline SN n & MM & Round & Smooth & White & Positive & Cocci \\
\hline SNo & NA & Round & Flower like & White & Positive & Cocci \\
\hline SN p & LB & Round & Smooth & Yellow & Positive & Rod \\
\hline SN q & LB & Mat forming & Smooth & White & Positive & Cocci \\
\hline SN r & LB & $\begin{array}{l}\text { Mat with } \\
\text { thread like } \\
\text { structures }\end{array}$ & $\begin{array}{l}\text { Feathery to } \\
\text { touch }\end{array}$ & Yellow & Positive & Cocci \\
\hline
\end{tabular}

Table.4 Comparison of the Antioxidant activities: DPPH radical scavenging and Ferrous chelation activity of the bacterial isolates from Kashmir and Kishtwar

\begin{tabular}{|c|c|c|c|c|}
\hline \multirow{2}{*}{$\begin{array}{c}\text { Concentration of } \\
\text { samples }\end{array}$} & \multicolumn{2}{|c|}{$\begin{array}{c}\text { DPPH radical scavenging } \\
(\text { OD at 517nm) }\end{array}$} & \multicolumn{2}{c|}{$\begin{array}{c}\text { Ferrous chelation } \\
(\text { OD at 562nm) }\end{array}$} \\
\cline { 2 - 5 } & Kashmir & Kishtwar & Kashmir & Kishtwar \\
\hline $\mathbf{2 0} \boldsymbol{\mu l}$ & $0.158 \AA$ & $0.312 \AA$ & $1.123 \AA$ & $1.024 \AA$ \\
\hline $\mathbf{4 0} \boldsymbol{\mu l}$ & $0.18 \AA$ & $0.335 \AA$ & $1.146 \AA$ & $0.99 \AA$ \\
\hline $\mathbf{6 0} \boldsymbol{\mu l}$ & $0.212 \AA$ & $0.359 \AA$ & $1.019 \AA$ & $0.987 \AA$ \\
\hline $\mathbf{8 0} \boldsymbol{\mu l}$ & $0.236 \AA$ & $0.372 \AA$ & $0.99 \AA$ & $0.963 \AA$ \\
\hline $\mathbf{1 0 0} \boldsymbol{\mu l}$ & $0.273 \AA$ & $0.391 \AA$ & $1.93 \AA$ & $\AA$ \\
\hline
\end{tabular}


Table.5 Percentage scavenging and percentage chelation

\begin{tabular}{|c|c|c|c|c|}
\hline \multirow{2}{*}{ Volume of extract } & \multicolumn{2}{|c|}{ \% Scavenging } & \multicolumn{2}{c|}{ \% Chelation } \\
\cline { 2 - 5 } & Kishtwar & Kashmir & Kishtwar & Kashmir \\
\hline $\mathbf{2 0} \boldsymbol{\mu l}$ & 70.6 & 85.13 & 5 & -4.3 \\
\hline $\mathbf{4 0} \boldsymbol{\mu l}$ & 68.5 & 83 & 8 & -6.5 \\
\hline $\mathbf{6 0} \boldsymbol{\mu l}$ & 66.2 & 80 & 9 & 5.5 \\
\hline $\mathbf{8 0} \boldsymbol{\mu l}$ & 65 & 77.84 & 10 & 7.99 \\
\hline $\mathbf{1 0 0} \boldsymbol{\mu l}$ & 63.2 & 74.32 & 12.71 & 19.6 \\
\hline
\end{tabular}

Table.6 Phenolic content

\begin{tabular}{|c|c|c|}
\hline \multirow{2}{*}{$\begin{array}{c}\text { Concentration } \\
\text { of samples }\end{array}$} & \multicolumn{2}{|c|}{$\begin{array}{c}\text { Phenolic content } \\
(\text { OD at 765nm) }\end{array}$} \\
\cline { 2 - 3 } & Kashmir & Kishtwar \\
\hline $\mathbf{2 0} \boldsymbol{\mu l}$ & $0.20 \AA$ & $0.13 \AA$ \\
\hline $\mathbf{4 0} \boldsymbol{\mu l}$ & $0.29 \AA$ & $0.14 \AA$ \\
\hline $\mathbf{6 0} \boldsymbol{\mu l}$ & $0.39 \AA$ & $0.20 \AA$ \\
\hline $\mathbf{8 0} \boldsymbol{\mu l}$ & $0.53 \AA$ & $0.29 \AA$ \\
\hline $\mathbf{1 0 0} \boldsymbol{\mu l}$ & $0.61 \AA$ & $0.34 \AA$ \\
\hline
\end{tabular}

Table.7 Flavonoid content

\begin{tabular}{|c|c|c|}
\hline \multirow{2}{*}{$\begin{array}{c}\text { Concentration } \\
\text { of samples }\end{array}$} & \multicolumn{2}{|c|}{$\begin{array}{c}\text { Flavonoid content } \\
\text { (OD at 510nm) }\end{array}$} \\
\cline { 2 - 3 } & Kashmir & Kishtwar \\
\hline $\mathbf{2 0} \boldsymbol{\mu l}$ & $0.15 \AA$ & $0.14 \AA$ \\
\hline $\mathbf{4 0} \boldsymbol{\mu l}$ & $0.16 \AA$ & $0.15 \AA$ \\
\hline $\mathbf{6 0} \boldsymbol{\mu l}$ & $0.25 \AA$ & $0.17 \AA$ \\
\hline $\mathbf{8 0} \boldsymbol{\mu l}$ & $0.30 \AA$ & $0.29 \AA$ \\
\hline $\mathbf{1 0 0} \boldsymbol{\mu l}$ & $0.42 \AA$ & $0.32 \AA$ \\
\hline
\end{tabular}

Table.8 Biochemical assay

\begin{tabular}{|c|c|c|}
\hline Assay & Kashmir & Kishtwar \\
\hline Tannins & + & ++ \\
\hline Coumerins & - & - \\
\hline Terpenoids & - & - \\
\hline Quinone & - & - \\
\hline Glycosides & + & + \\
\hline
\end{tabular}


Fig.1 Gel picture showing metagenomic DNA isolated from stigma of Kashmir and Kishtwar.

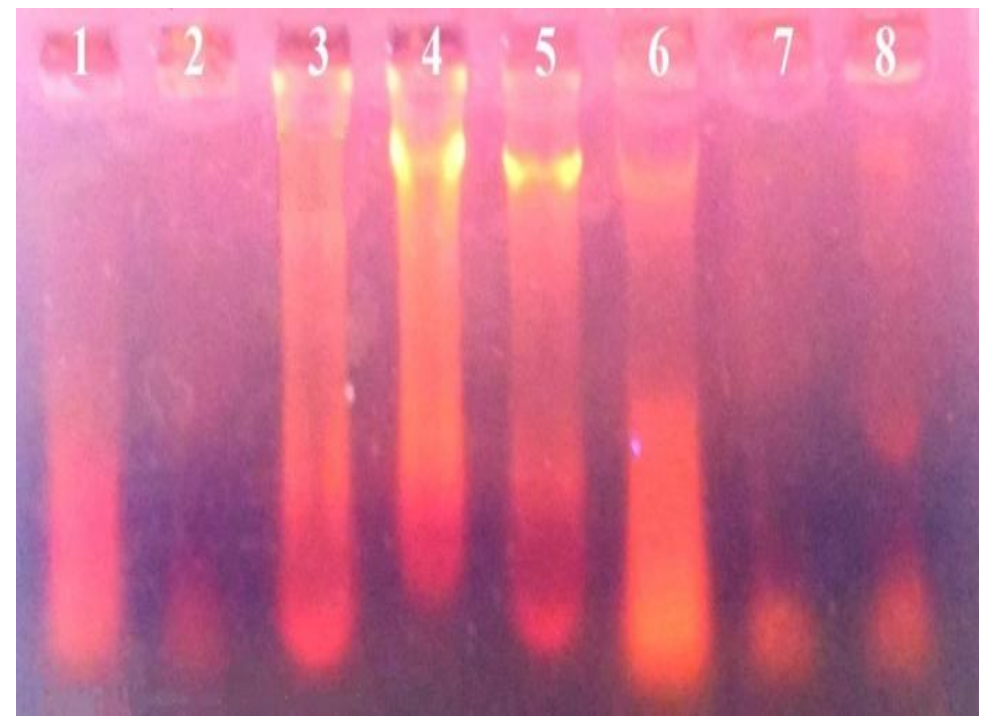

Fig.2 Various morphotypes from a) Kashmir and b) Kishtwar
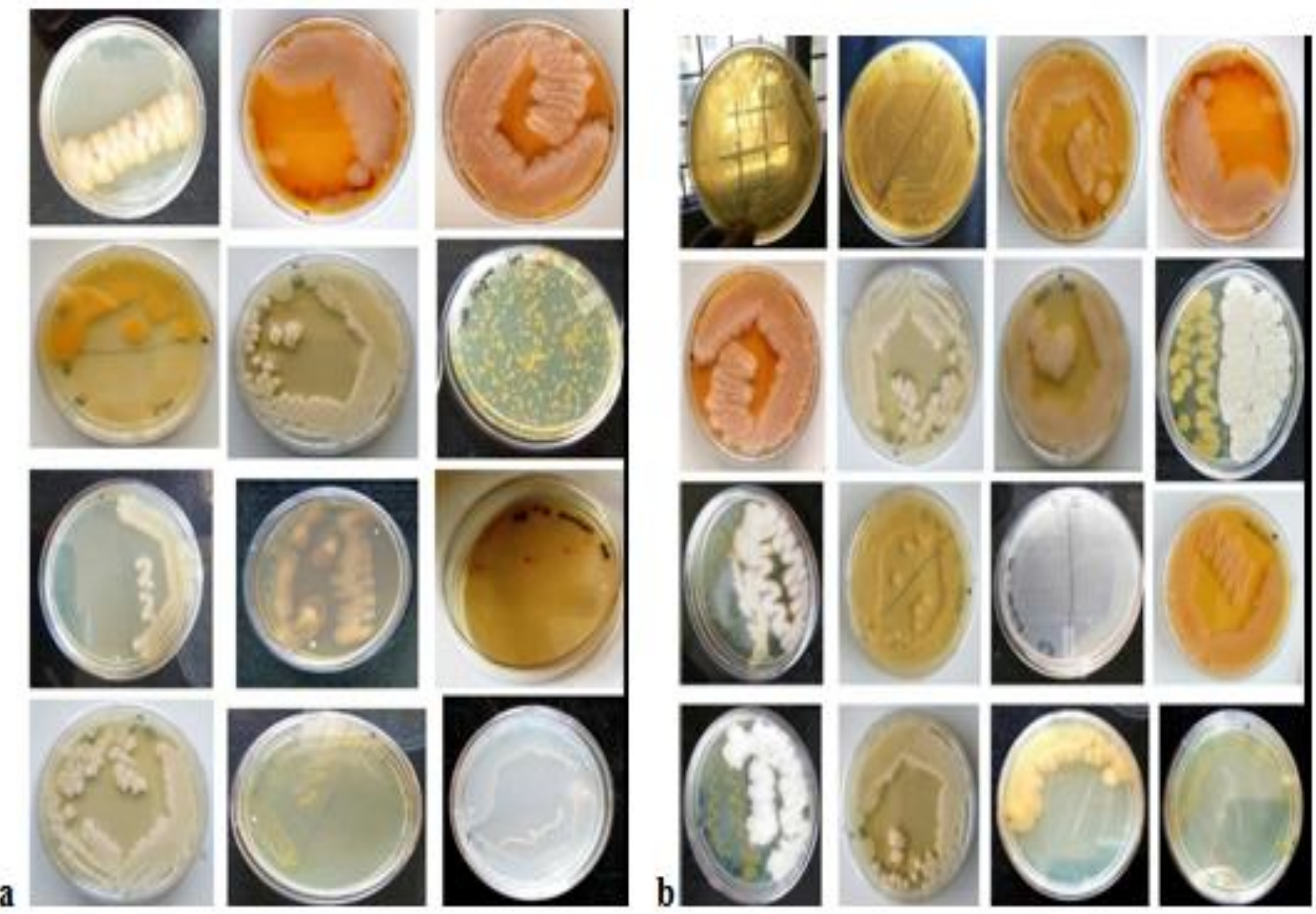
Fig.3 Graphs showing the differences in texture in Saffron from Kashmir and Kishtwar. Smooth textured colonies are more in Kishtwar whereas Rough textured colonies are more in case of

Kashmir

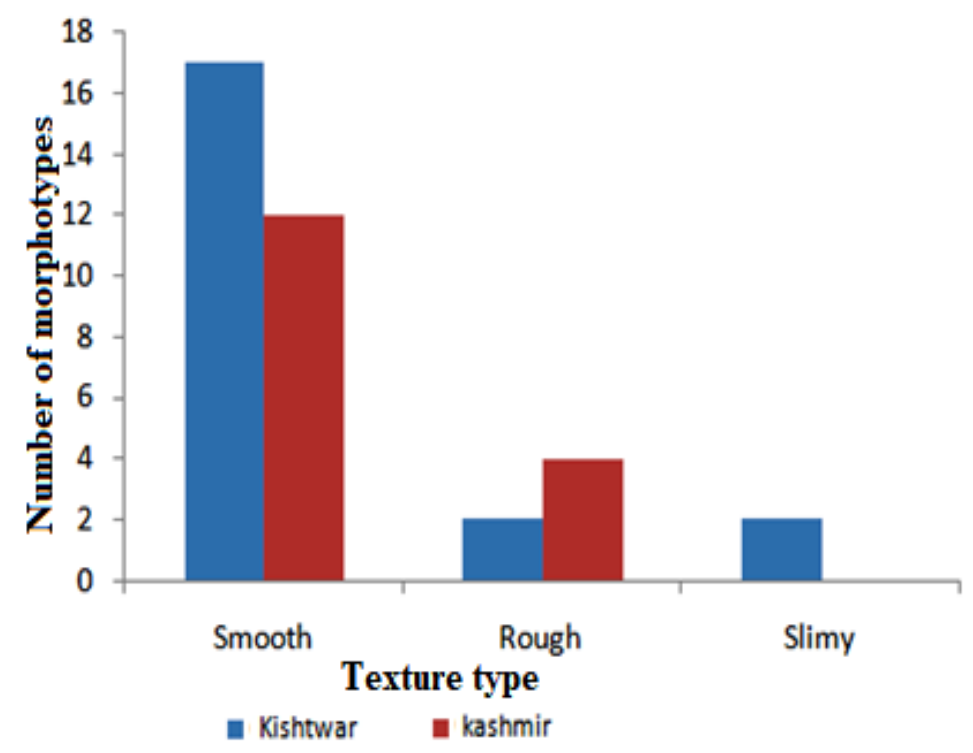

Fig.4 Graphs showing the differences in gram's staining in Saffron from Kashmir and Kishtwar. Theisolates from the stigma were all grams positive rods or cocci and no grams negative bacteria were isolated.

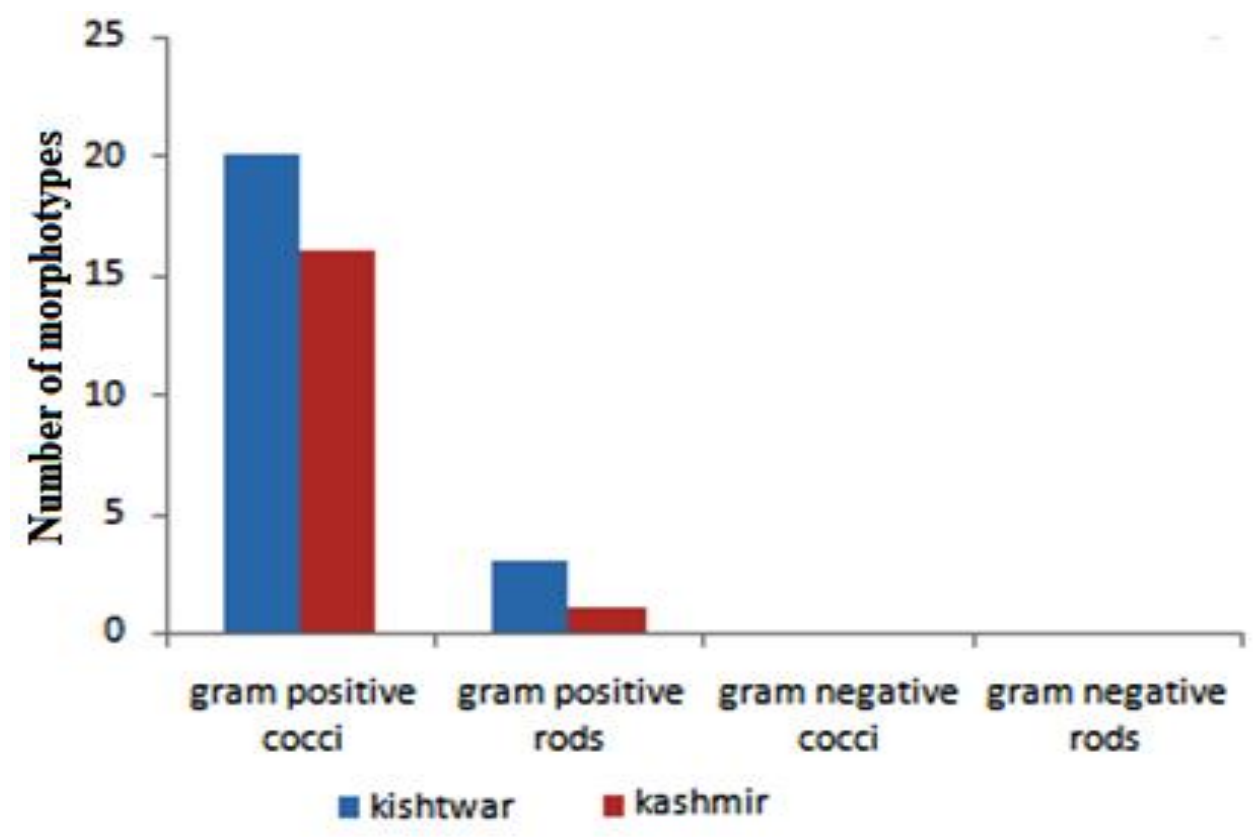


Fig.5 Antioxidant properties of extracts from Saffron.

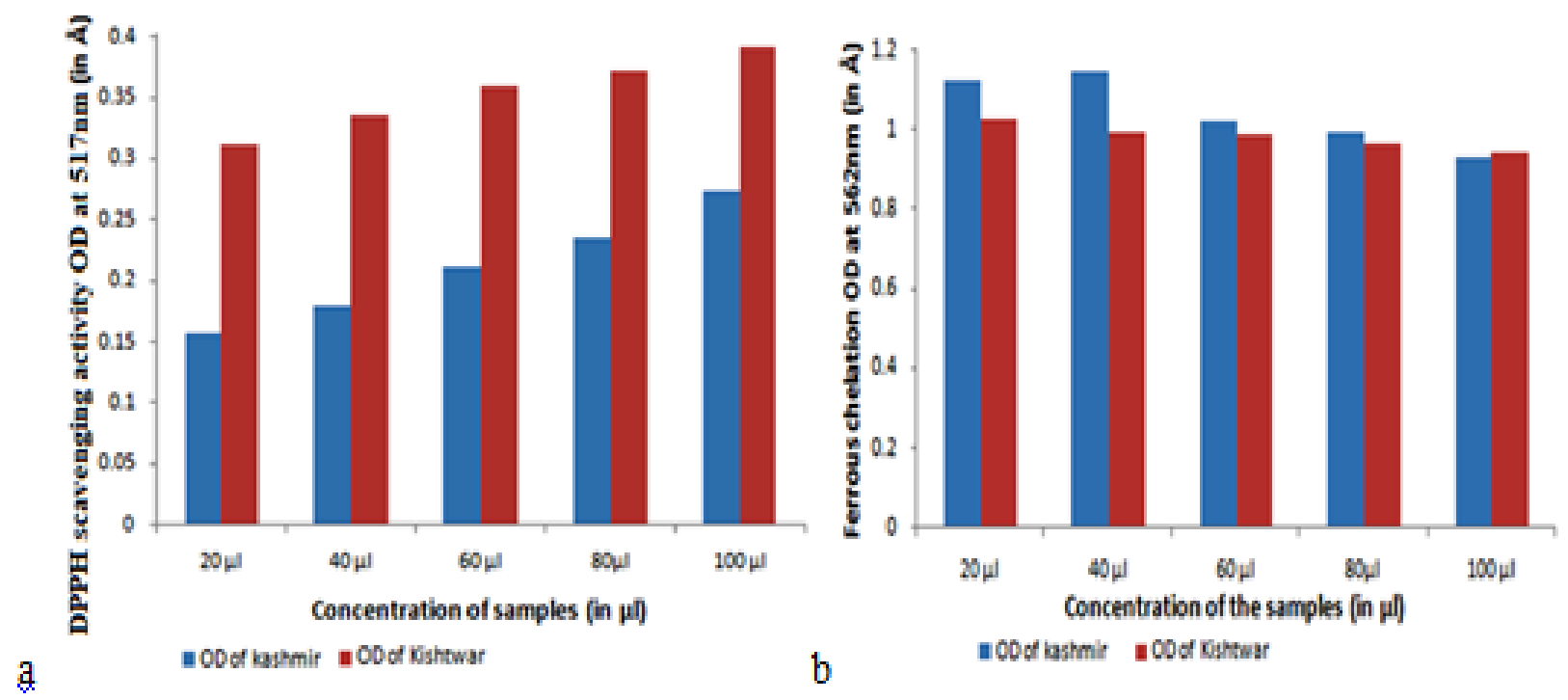

Fig.6 Antioxidant free radical scavenging and Ferrous chelation properties of the extracts of the bacterial isolates: The above graphs show that the a) Percentage scavenging activity of extract from Kashmir is less than that of Kishtwar. Hence, Kishtwar has more antioxidant property (scavenging decreases with increase in the concentration, the antioxidant property is increasing). b) Percentage chelation is more in extracts from Kashmir than that of Kishtwar. Hence, Kishtwar has more antioxidant property (chelation increases with increase in concentration, antioxidant property increases).

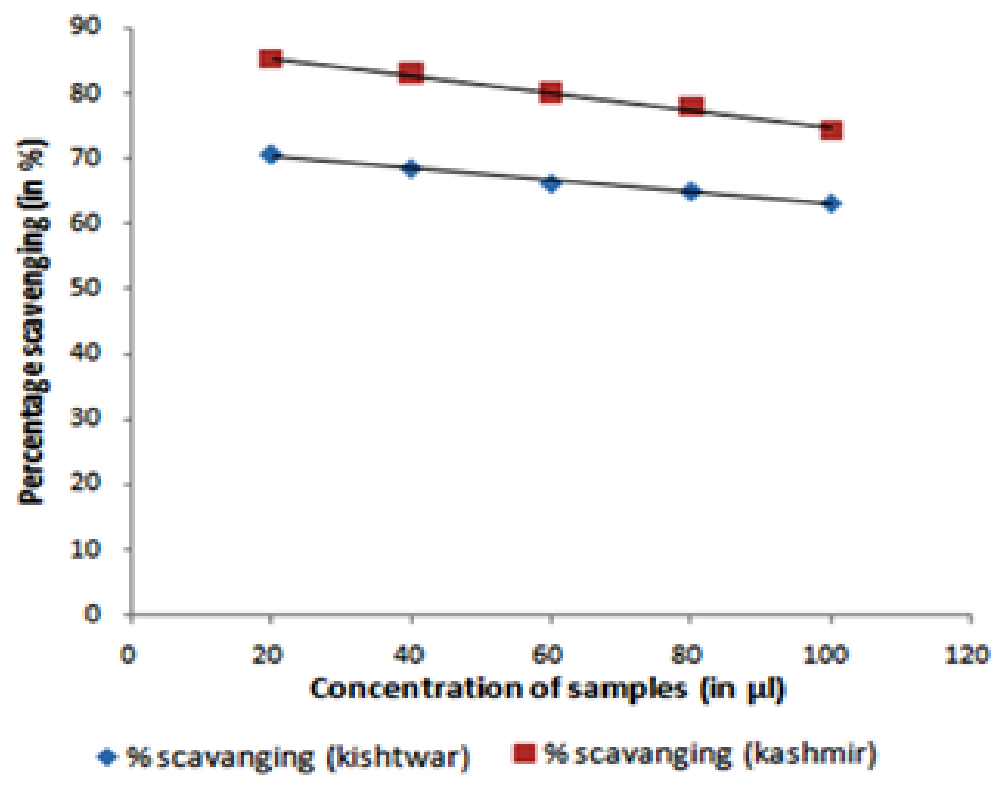




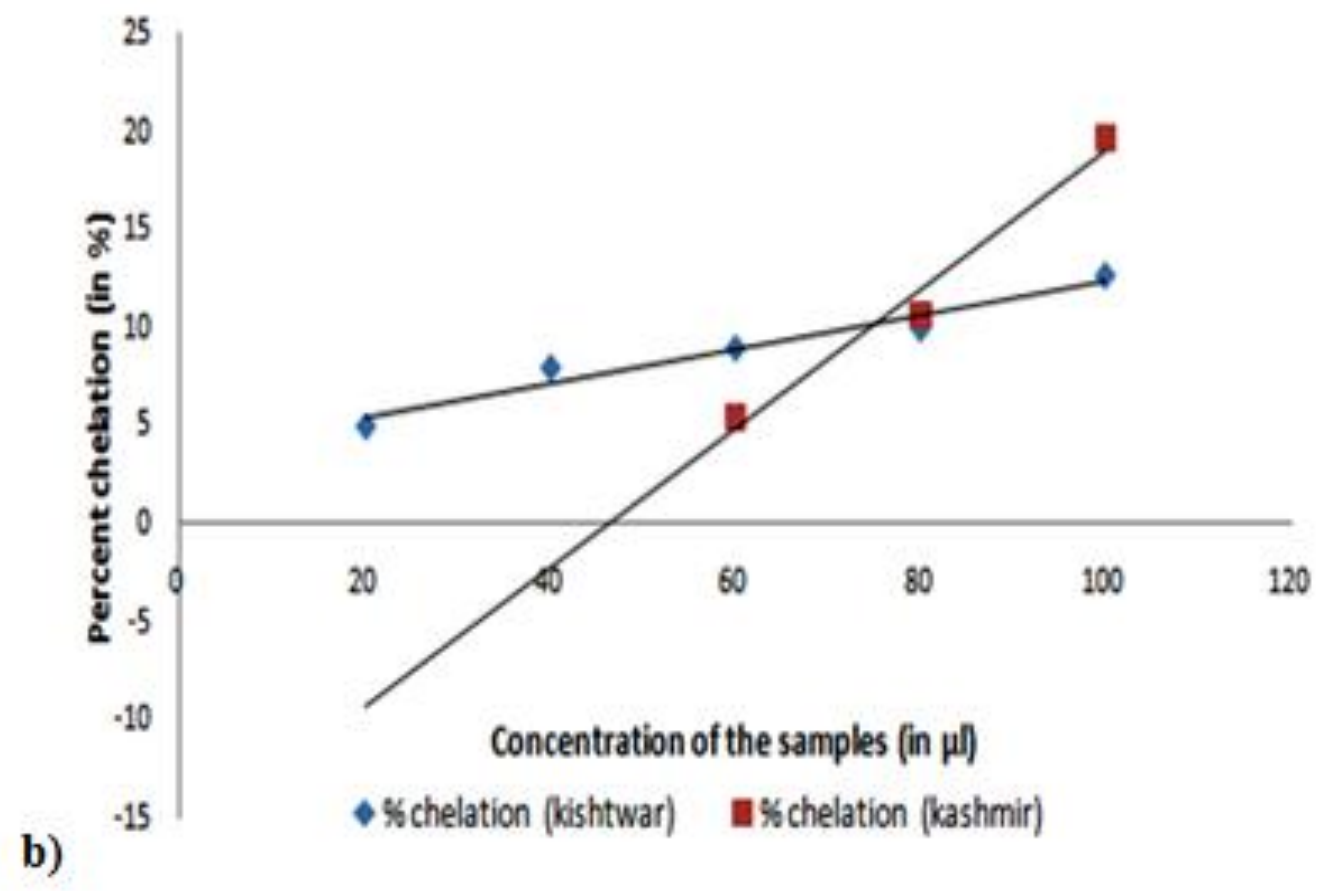

Fig.7 Phenolic content: Phenolic content of the extracts of Kishtwar is more than that of the phenolic content of the extracts of Kashmir.

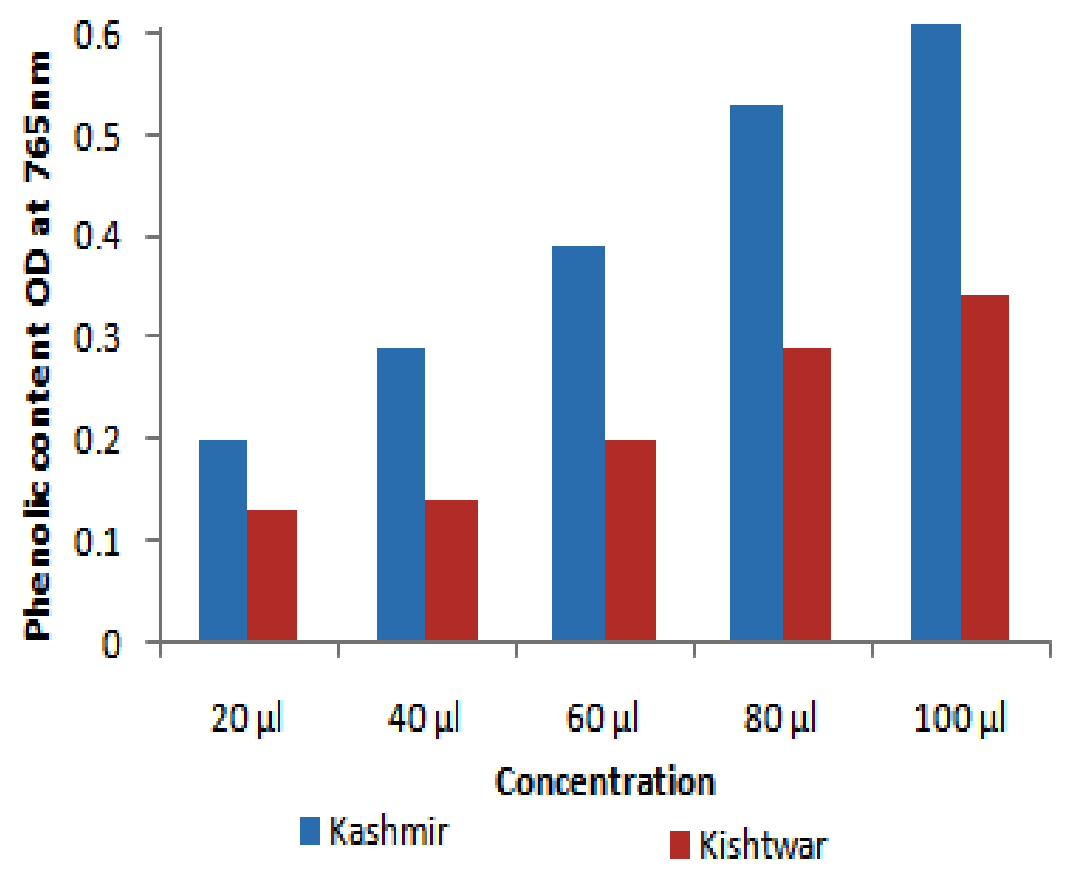


Fig.8 Flavonoid content: Flavonoid content of the extracts of Kishtwar is more than that of the Flavonoid content of the extracts of Kashmir.

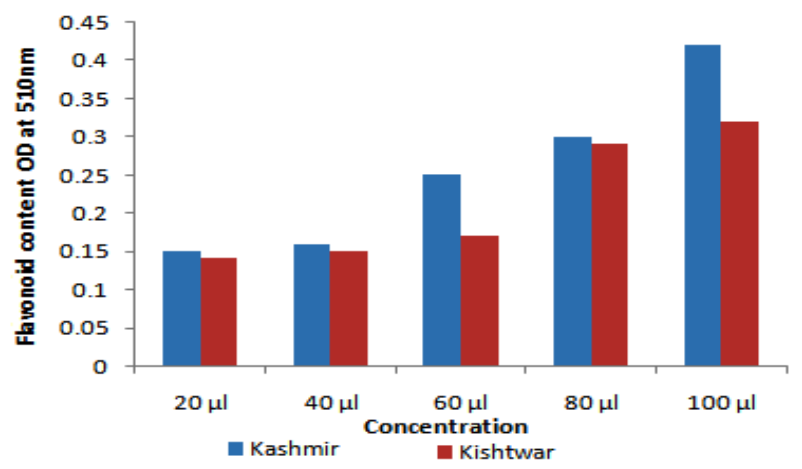

Fig.9 Biochemical assay. It shows that tannins and glycosides are present in the extracts of microbes from the stigma of Kashmir and Kishtwar.

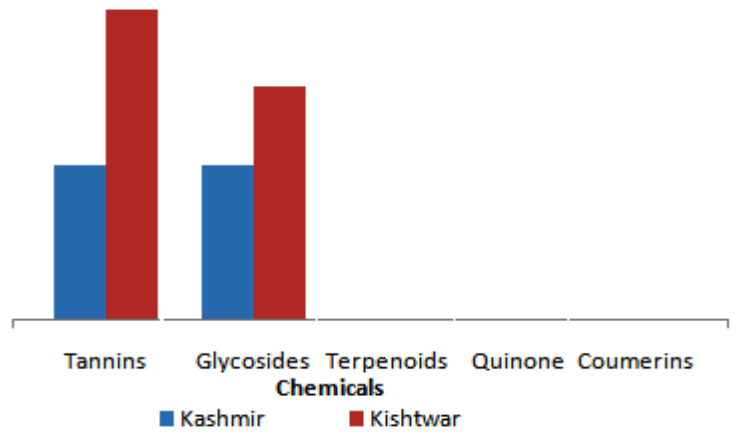

The $\mathrm{IC}_{50}$ values of radical scavenging revealed that antioxidant activity of Kishtwar is more as lower $\mathrm{IC}_{50}$ value corresponds to a higher antioxidant activity of sample. The $\mathrm{IC}_{50}$ values of ferrous chelation revealed that antioxidant activity of Kishtwar is more as lower $\mathrm{IC}_{50}$ value corresponds to a higher antioxidant activity of sample. Hence, Kishtwar has more antioxidant activity. The flavonoid and phenolic content of Kashmir is higher than that of Kishtwar. Of the biochemical assays conducted, only tannins and Glycosides are present in stigma of saffron.

The Metagenomic DNA isolated methods used are used for soil samples. Hence, the Metagenomic DNA was not isolated in the purified form and hence could not be sequences. This needs further study for standardizing a protocol for Metagenomic DNA from stigma samples. Further work can be done to unveil the bacterial property to produce the pigments that act as favouring agent that can be used in bio-industry.

\section{References}

Braca,A., Tommasi, N. D., Bari, L. D., Pizza, C., Politi, M., Morelli, I. (2001). Antioxidant principles from Bauhinia terapotensis. J. Nat. Prod. 64: 892-895.

Carter, C. W., Freer, S. T., Xuong, N. H., Alden, R. A., Kraut, J. (1971). Cold spring harbour symp. Quant. Biol. 36,381.

Chang, C., Yang, M., Wen, H., Chern. J. (2002). Estimation of total flavonoid content in propolis by two complementary colorimetric methods. Journal of Food Drug Analaysis, 10: 178-182. 
Chen, X. H., Koumoutsi, A., Scholz, R., Eisenreich, A., Schneider, K., Heinemeyer, I. (2007). Comparative analysis of the complete genome sequence of the plant growth-promoting bacterium Bacillus amyloliquefaciensFZB42. Nat Biotechnol

Gilbert, J. A., Meyer, F., Jansson, J., Gordon, J., Pace, N., Tiedje, J., Ley, R., Fierer, N., Field, D., Kyrpides, N., Glöckner, F. O., Klenk, H. P., Wommack, K. E., Glass, E., Docherty, K., Gallery, R., Stevens, R., Knight, R. (2010) The Earth Microbiome Project: meeting report of the "1st EMP meeting on sample selection and acquisition" at Argonne National Laboratory October 6 2010. Stand Genomic Sci.; 3:249-253.

Kent, A. D., Triplett, E. W. (2002) Microbial communities and their interactions in soil and rhizosphere ecosystems. Annu Rev Microbiol; 56:211-236.

Kim-kwon, B., Chung, J. H., Kim, S. Y., Jeong, H., Kang, S. G., Kwon, S. K., Lee, C. H., Song, J. Y., Yu, D. S., Ryu, C. M., and Kima, J.F. (2012) Bacteria 5B6 colonizing the phyllosphere acting as biocontrol agent. Genome Announcement.194: 3758 3759

Negbi, M. (1999). Saffron cultivation: past, present and future prospects. In: Negbi, M. (Ed), Saffron: Medicinal and Aromatic plants - Industrial Profiles, Vol. 8: Crocus sativus. Harwood Academic Publishers, Australia. 1-18.

Oldroyd, G. E. D., Murray, J. D., Poole, P. S., Downie, J. A. (2011) The rules of engagement in the legume rhizobial symbiosis. Annu Rev Genet; 45:119-144.

Ottesen, A. R., Pena, A. G., and White, J. R., (2013) Baseline survey of the anatomical microbial ecology of an important food plant: Solanum lycopersicum (tomato). BMC Microbiol.; 13:114.

Pang, Y. W., Duan, L. Z., Song, D. Y., Ren, Z. M. (2011). A modified method of genomic DNA extraction and establishment of AFLP systems in Rhuschinensis. Guihaia. 31: 36-38.

Pinelo, M., Rubilar, M., Sineiro, J. and Núñez, M. J. (2004). Extraction of antioxidant phenolics from almond hulls (Prunusamygdalus) and pine sawdust (Pinuspinaster). Food Chemistry. 85:267273.

Turnbaugh, P. J., Ley, R. E., Hamady, M., FraserLiggett, C. M., Knight, R., Gordon, J. I. (2007). The Human Microbiome Project. Nature. 449:804-810.

Wani, M. A. (2004) Studies on saffron corm roots Phd thesis, Sher-e-Kashmir university of Agricultural science and technology of Kashmir, India. 108.

Wechter, P., Williamson, J., Robertson, A., Kluepfel, D. (2003). A rapid cost-effective procedure for the extraction of microbial DNA from soil. World Journal of Microbiology \& Biotechnology, New York. 19: 85-91.

Zhao, B., Gao, Z., Shao, Y., Yan, J., Hu, J., Yu, J., Liu, Q., and Chen, F. (2011) Diversity analysis of type I ketosynthase in rhizosphere soil of cucumber. Journal of Basic Microbiology. 52: 2(224).

\section{How to cite this article:}

Mridhu Sharma, Puneet Gupta, Shanu Mangotra, Sneha Ganjoo, Deepika Trakroo, Sakshi Sharma and Jyoti Vakhlu. 2021. Isolation and Biochemical Analysis of Bacteria associated with Dried Stigma of Saffron (Crocus sativus). Int.J.Curr.Microbiol.App.Sci. 10(05): 112-126. doi: https://doi.org/10.20546/ijcmas.2021.1005.016 